\title{
Financial Transaction Tax in Tehran Stock Exchange (Composition Versus Liquidity Effect)
}

\author{
Parvaneh Motie ${ }^{1}$ \\ Ali Mazyaki² \\ Hossein Panahiyan ${ }^{3}$ \\ Hassan Ghodrati ${ }^{4}$
}

mazyaki@atu.ac.ir

h.panahian@iaukashan.ac.ir

Received: 08/06/2021 | Accepted: 09/09/2021

\begin{abstract}
Policymakers attempt to improve the market quality of stock exchanges by implementing various regulations. Even though the transaction tax has always affected exchanges, the consequences of such a policy on various aspects of market quality have often been understudied in Iran. Thus this paper, using high-frequency data of 422 companies in the period from June to November 2018, investigates the effect of reducing transaction tax in different quality measures of Tehran Stock Exchange. Considering the fact that reduction of transaction tax in September 2018 has not been applied to investment funds, the DID approach has been implemented. According to the results, the reduction of transaction tax in September 2018 has increased the volume of transactions and market efficiency, while market volatility has decreased in effect. This result, therefore, confirms the liquidity versus composition effect through which the reduction of transaction tax increases the market efficiency by an increment of liquidity.
\end{abstract}

Keywords: Financial Transaction Tax, Liquidity Effect, Composition Effect, Market Efficiency, Market Depth.

JEL Classification: G10, G14, G18, G23.

1. Ph. D. Student, Department of Accounting, Islamic Azad University, Kashan Branch, Kashan, Iran

2. Assistant Professor of Economics Department, Allameh Tabataba'i University (ATU). (Corresponding Author)

3. Associate Professor, Department of Accounting, Islamic Azad University, Kashan Branch, Kashan, Iran.

4. Assistant Professor, Department of Accounting, Islamic Azad University, Kashan Branch, Kashan, Iran. 


\title{
ماليات انتقال سهرام در بورس اوراق بهادار تهران

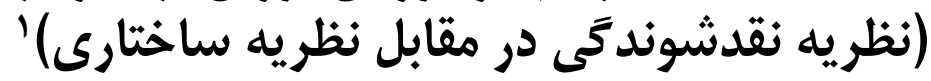

\author{
يروانه مطيع \\ دانشجوى دكترى كروه حسابدارى، واحد كاشان، دانشعاه آزاد اسلامى، كاشان، ايران. \\ mazyaki@atu.ac.ir

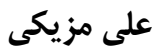

استاديار كروه اقتصاد، دانشكاه علامه طباطبايى، تهران، ايران (نويسنده مسئول). h.panahian@iaukashan.ac.ir |

حسين پيناهيان دانشيار گروه حسابدارى، واحد كاشان، دانشخاه آزاد اسلامى، كاشان، ايران. حسن قدرتى استاديار تروه حسابدارى، واحد كاشان، دانشعاه آزاد اسلامى، كاشان، ايران.

קجيده: سياستخذاران بازار سرمايه سعى دارند با استفاده از ابزارهاى مناسب موجب بهبود ابعاد

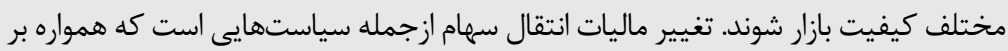

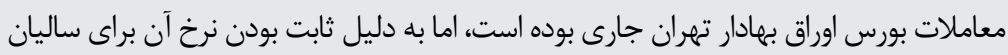

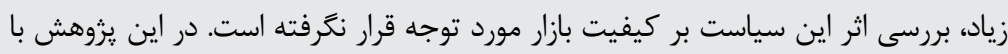

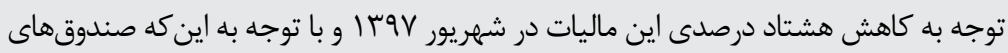

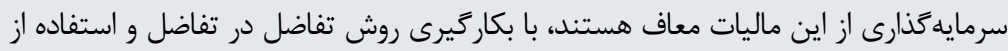

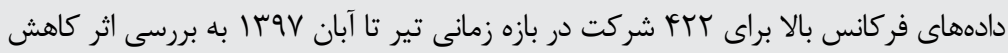

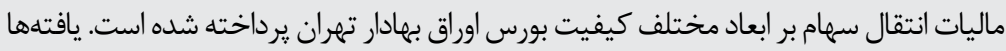

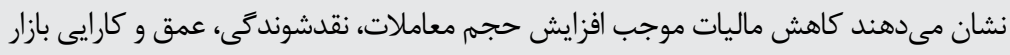

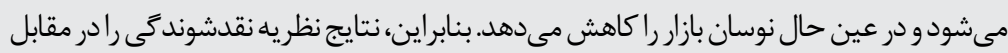

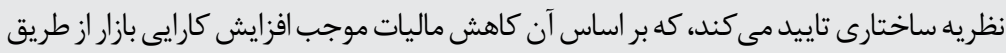
افزايش نقدشوندكى مىشود.

كليدوازهها: ماليات مبادله سهام، اثر نقدشوندگى، اثر ساختارى، كارايى بازار، عمق بازار. طبقهبندى G23, G18, G14, G10 :JEL. ا. اين مقاله از رساله دكترى نويسنده اول در دانشعاه آزاد اسلامى واحد كاشان استخراج شده است. 


\section{مقلم}

ابعاد مختلف كيفيت بازار سهام نشاندهنده توان تامين مالى بازار سرمايه يك كشور و همجنين،

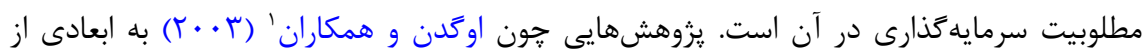
كيفيت بازار سهام مانند هزينه معاملات، فر كانس (تعداد دفعاتى كه يك دارايى دادوستد مىشود)، شفافيت اطلاعاتى، نوسان قيمت، گردش سهام، سهام شناور، و سود معاملات اشاره مى كنند. البته از

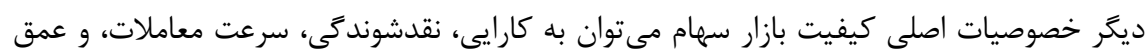

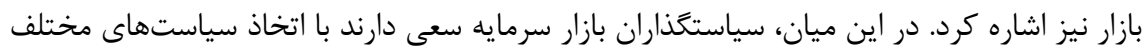

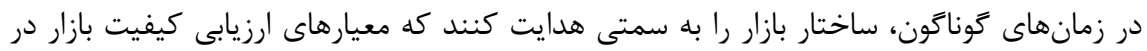

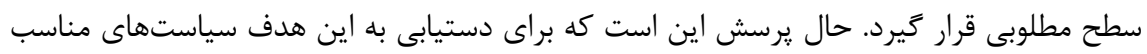

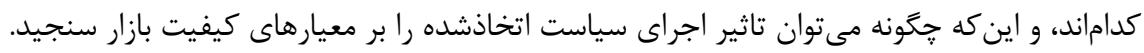

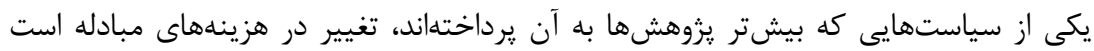

Bagheri et al., 2014; Mani et al., 2011; Mousavi Jahromi et al., 2017; Atrchi \& Ramtinnia, 2018)

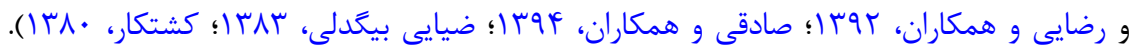
هزينههاى مبادله در بازار بورس اوراق بهادار تهران شامل كارمزد معاملات و ماليات انتقال سهام است.

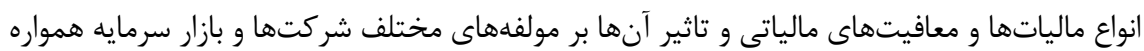
مورد توجه يزوهشكران حوزه مالى بوده است. ماليات انتقال سهام يكى از انواع ماليات است كه اخرجه.

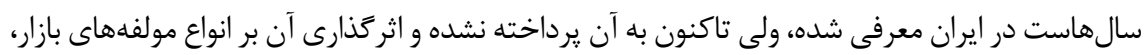
همجون كارايى، مورد بررسى قرار نخرفته است.

با توجه به اينكه نرخ ماليات انتقال سهام ساليان زيادى است بدون ترورن تغيير مانده، بنابراين تغيير

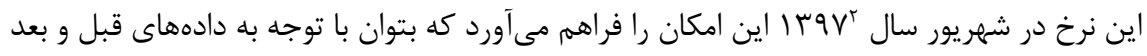

\section{Ogden et al.}

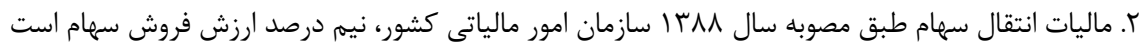

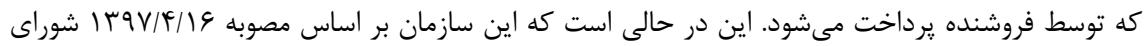

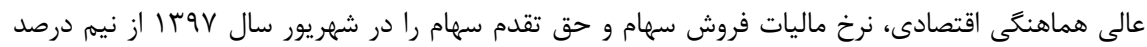

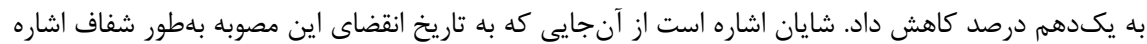

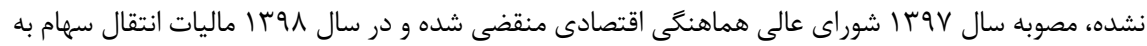
همان نيم درصد سابق بازگشته است. براى اطلاعات بيشتر به تاركاه زير مراجعه نماييد: https://www.seo.ir/Üpload/Editor/Files/Nahade\%20Mali/moghararte\%20Mokhtas/Ghanon-\%20tose-Abzarha.PDF 
از تغيير نرخ، اثر تغيير در نرخ ماليات را بر مولفههاى مختلف بازار بررسى كرد؛ در حالى كه اين بررسى

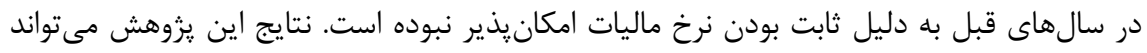

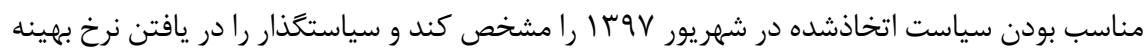
ماليات براى دستيابى به بازارى باكيفيتتر يارى رساند. شايان اشاره است كه براى بالا بردن دقت

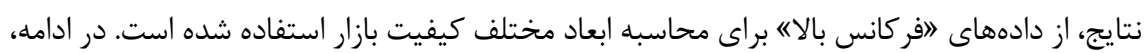

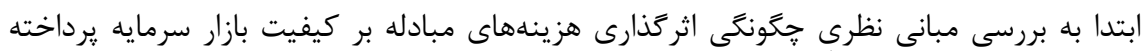

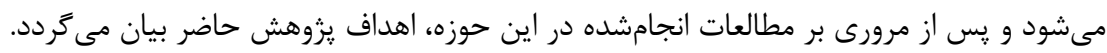

\section{مبانى نظرى يزوهش}

بررسى سازوكار اثرگذارى هزينههاى مبادله بر ابعاد مختلف كيفيت بازار سرمايه مىتواند

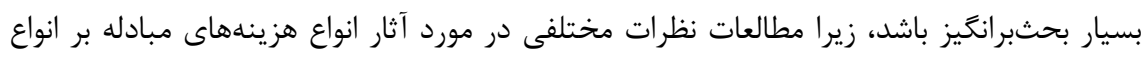

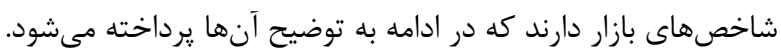

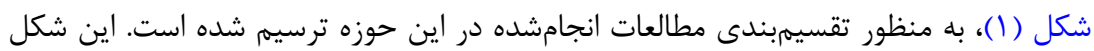

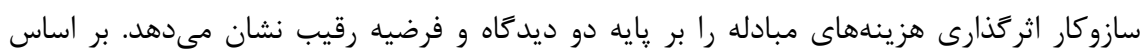

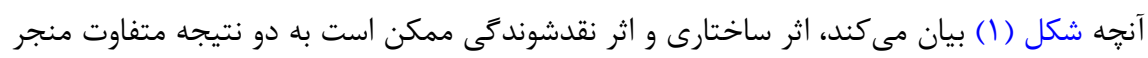

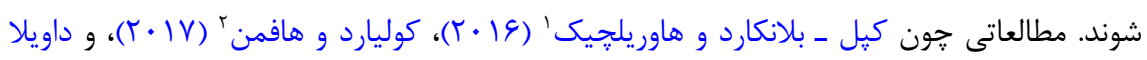

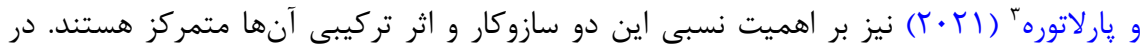

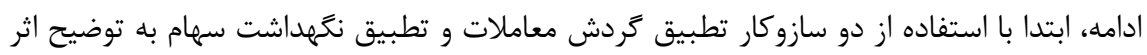

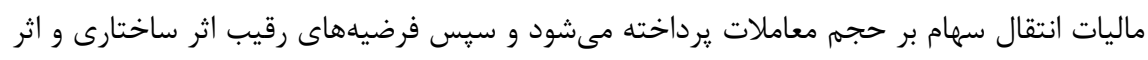
نقدشوندگى توضيح داده مىشوند.

1. Capelle-Blancard \& Havrylchyk 


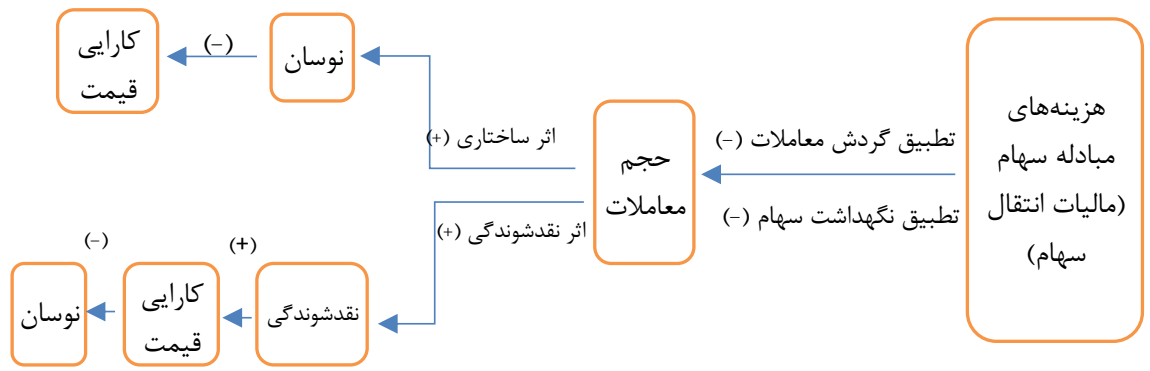

شكل 1: سازوكار اثر كذارى هزينهاى مبادله بر كارايى بازار

نظريههاى قيمتخذارى دار ايىهاى سرمايهاى بر مبناى هزينههاى مبادله بر دو سازوكار مختلف تاكيد دارند كه به واسطه آنها هزينههاى مبادله بر حجم معاملات تاثير مى گذارند. اين دو فرضيه نبايد به عنوان

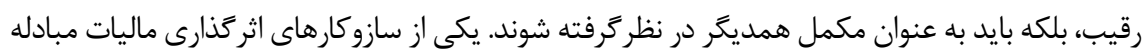
بر حجم معاملات از طريق تطبيق كردش معاملات' است، جرا كه يكى از متغيرهايى كه در اثر تغيير

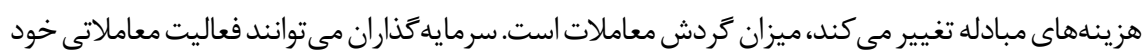

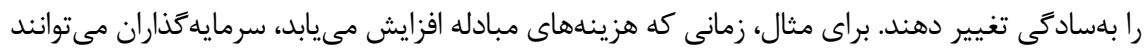

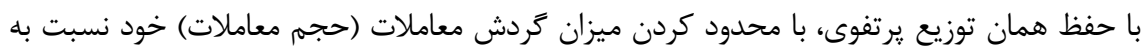

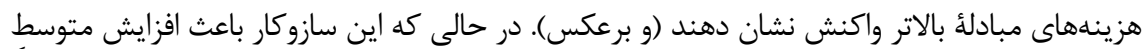
دوره نكهداشت سهام براى سهام تاثيريذيرفته از هزينه مبادله (ماليات انتقال سهام) مىشود، اما بهدرستى

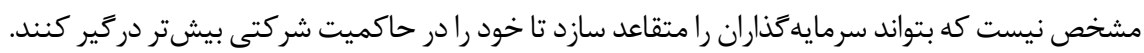

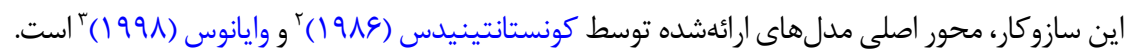

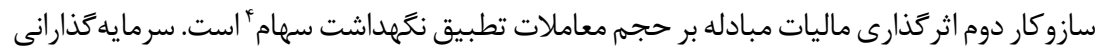

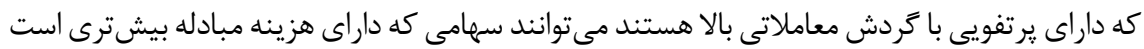

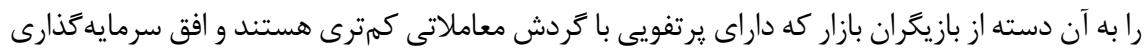

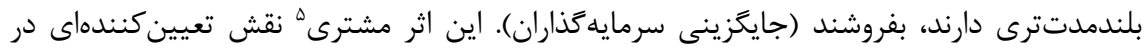

1. Turnover Adjustment

2. Constantinides

3. Vayanos

4. Holding Adjustment

5. Clientele Effect 
يروهش آميهود و مندلسون' (919 () ايفا مى كند. آنها نشان مىدهند دارايىهايى كه از هزينههاى

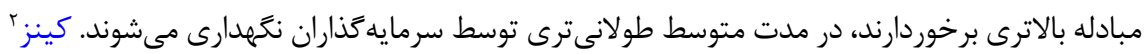

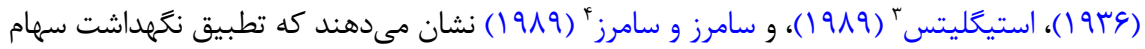
باعث خواهد شد كه نفوذ سهامداران بلندمدت افزايش يابد و به تصميمهاى شركتى بهترى بينجامد، زيرا سرمايهَذاران در حاكميت شركتى بيشتر درگير مىشوند.

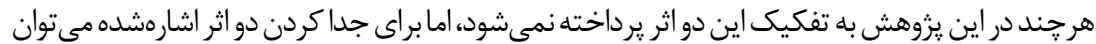

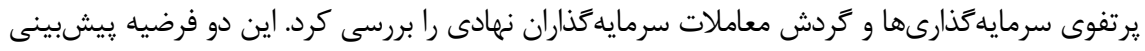

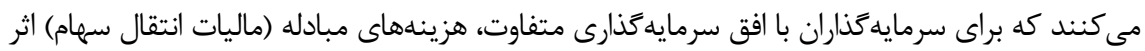

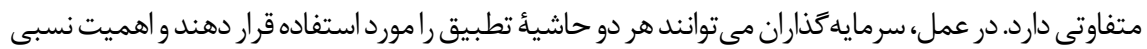

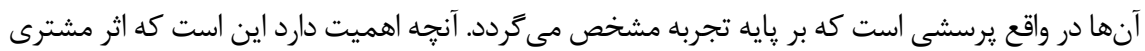
نقشى تعيين كننده در ادبيات هزينههاى مبادله سهام بازى مى كند. هر جند شايد اين گونه به نظر برسد كه تغيير

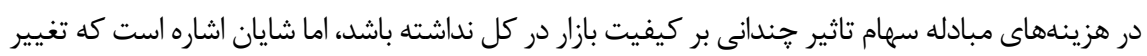
هزينههاى مبادله در تغيير نحوه تخصيص يرتفو ورفتار معاملاتى بازيگران بازار قابلملاحظه است. در ادامه دو سازوكار اثركذارى ماليات انتقال سهام، كه فرضيههاى آزمونيذيرى ايجاد مى كنند، بيان مىشوند. اثر ساختارى و اثر نقدشوندگى در حقيقت دو سازوكار مختلف اثرگذارى تغيير حجم معاملات بر ماري نوسان، نقدشوندگى، و كارايى قيمت را مطرح مى كنند كه مدل مفهومى آن در شكل ( (1) نمايش داده شد.

\section{اثر ساختارىه}

بر طبق اين نظريه، افزايش هزينههاى مبادله سهام مىتواند از طريق تغيير تركيب جمعيتى معامله كران، نوسان را كاهش دهد و عدم بازدهى بازار را اصلاح كند. اين نظريه كه رويكرد خوشبينانهترى نسبت به هزينههاى مبادله دارد، به اثر ساختارى معروف است. براى مثال، استيخليتس (9199 (19) بيان

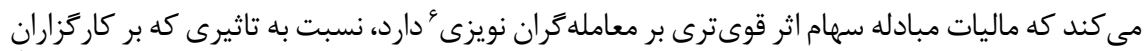
با اطلاعات بنيادى دقيق مى گذارد. انتظار مىرود تغيير ايجادشده در جمعيت معاملهَران، نوسانهاى

1. Amihud \& Mendelson

2. Keynes

3. Stiglitz

4. Summers \& Summers 
غيربنيادى' را كاهش دهد و بازدهى قيمت را بهبود بخشد. مطابق نظريه استيخليتس (9/9 ()، فعاليت معاملاتى برخى بازيخران بازار داراى اثرات جانبي منفى در بازار است. همزمان، سوداگران نسبت به به به

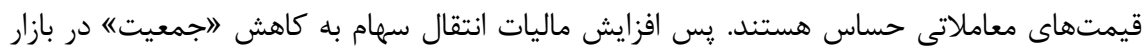
كمك خواهد كرد. كاهش جمعيت به كاهش نوسان، افزايش كارايى قيمت و در يى آن افزايش كيفيت

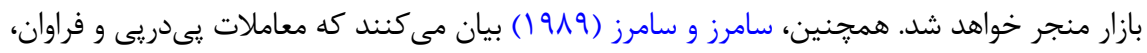

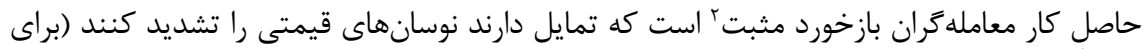

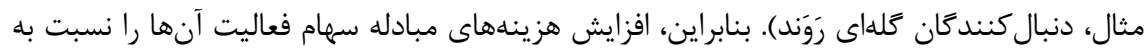
فعاليت معاملهكران بنيادى، بيشتر كاهش مى دهدي.

اثر نقدشوندگى

مخالفان افزايش ماليات انتقال سهام، بامطرح كردن اثر نقدشوندگى اهميت و ارزش اقتصادى و همجنين

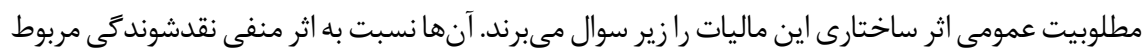
به كاهش گسترده در فعاليتهاى معاملاتى به دليل افزايش قيمت معاملات هشدار مى دهند. اين ديدگاه رقيب، متكى بر اثرات جانبى قدرتمند نقدشوندگى در بازارهاى مالى است كه اثرات غيرمستقيم افزايش

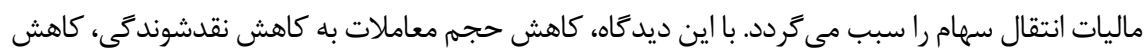

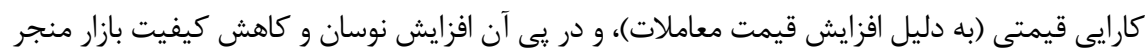

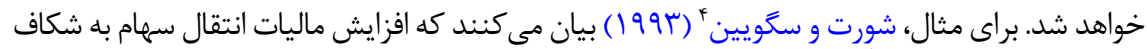
بيشتر در قيمتهاى خريد و فروش به علت كاهش حجم معاملات، افزايش هزينه هاى هجينَّهُ، و و افزايش

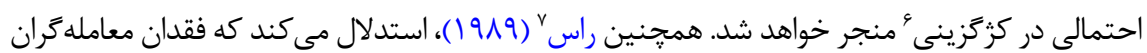
كوتامدت به واسطة موقعيت موجودى يرهزينهُ براى تامين نقدينكى از دارايىها، به نقدشوندكى صدمه

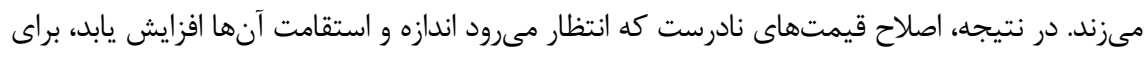

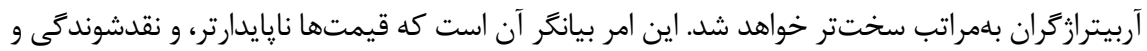

1. Non-Fundamental Volatilities

2. Positive Feedback Traders

3. Liquidity Effect

4. Schwert \& Seguin

5. Hedging Cost

6. Adverse Selection

7. Ross

8. Costly Inventory Position 
كارايى نيز كمتر خواهند شد. سونگ و جانگً' (ه · ·r)، يك مدل موازنهاى ارائه مى كنند كه در آن هر دو

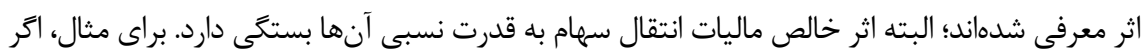

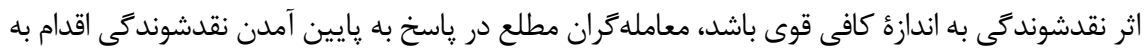
كاهش فعاليتهاى معاملاتى خود خواهند كرد. در اين حالت، نوسان افزايش و كارايى قيمتى تنزل مىيابد.

\section{روش}

\section{مدل}

هدف كلى اين يزوهش، از يك طرف بررسى تاثير تغيير در ماليات انتقال سهام بر معيارهاى كيفيت بازار ازجمله حجم، نوسان، كارايى قيمت، نقدشوندگى، و عمق بازار است و از طرف ديكر، به مقايسه فرضيههاى رقيب اثر ساختارى و اثرنقدشوندگى در بورس اوراق بهادار تهران در رابطه با تغيير باري

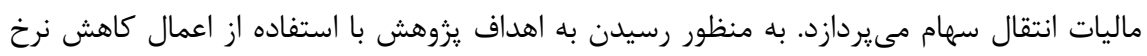

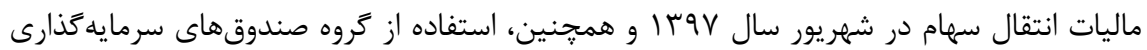

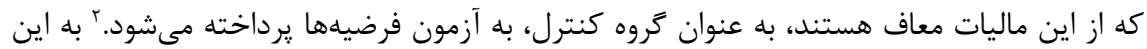

\section{Song \& Zhang}

ז. شايان ذكر است اگرجه شباهت گروه تيمار و كنترل در موارد بسيارى كم نيست و اين موضوع در جدول ميانخين متغيرهاى مورد بررسى قابل مشاهده است:

\begin{tabular}{|c|c|c|c|c|c|c|c|}
\hline Variables & $\begin{array}{c}\text { log_vol_ } \\
\text { trade }\end{array}$ & $\begin{array}{c}\text { r_vola- } \\
\text { tility }\end{array}$ & Range & $\begin{array}{c}\text { price_- } \\
\text { efficiency }\end{array}$ & $\begin{array}{l}\text { quoted } \\
\text { spread }\end{array}$ & $\begin{array}{c}\text { effective } \\
\text { spread }\end{array}$ & Depth \\
\hline \multirow{2}{*}{ Treatment Group } & $\wedge$ & $\tau$ & 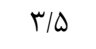 & את. & & & \\
\hline & $(T / \Gamma q)$ & $(\xi / \cdot 1)$ & $(\Gamma / Q)$ & $(\cdot / / V)$ & $(\cdot / 1)$ & $(\cdot / 1)$ & $(\varphi / \Lambda)$ \\
\hline \multirow{2}{*}{ Control Group } & $5 \cdot 119$ & r/GF & $1 / 4$ & $\cdot / T F$ & $r \cdot 119$ &.$/ \cdot r$ & M \\
\hline & $(T / F F)$ & $(\uparrow q / 4)$ & $(T / \Delta V)$ & $(\cdot / / \mathrm{V})$ & $(T / F Y)$ & $(\cdot / \cdot V)$ & $(\cdot / 4)$ \\
\hline
\end{tabular}

اما خصوصيت اصلى مشترك سهام صندوقهاى سرمايه كذارى و ساير سهمهاى مورد بررسى، قابلمعامله بودن

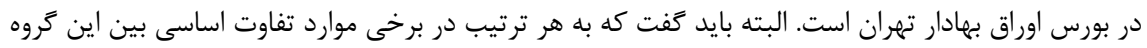

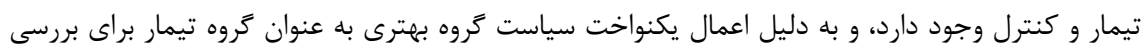

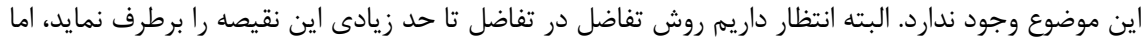

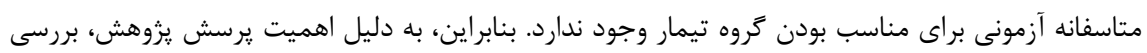

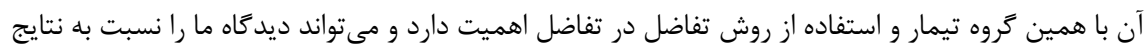

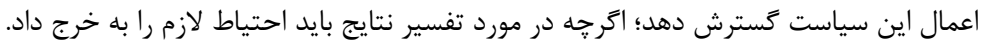




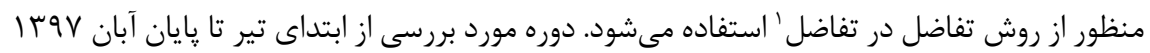

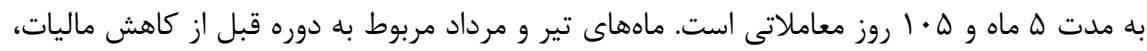

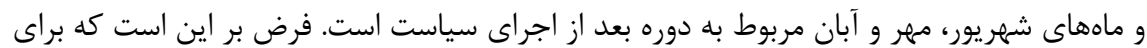

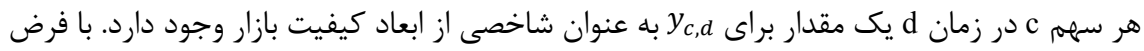

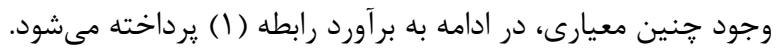

$y_{c, d}=\alpha_{c}+\gamma_{d}+\beta^{a f t e r} D_{c, d}^{a f t e r}+\epsilon_{c, d}$

كه در آن d اثرات ثابت زمانى و co مربوط به اثرات ثابت شركتى است كه البته به دليل برخورد به مشكل همبستخى متغيرهاى مستقل نمى توان آنها را در تخمين شامل كرد. اثر قرار كرفتن انجام

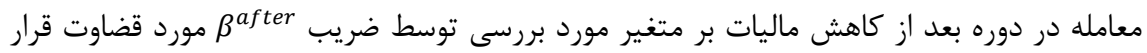

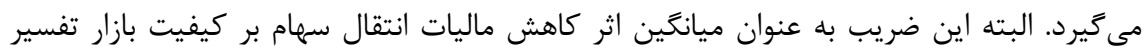
مىشود و در ادامه براى شناسايى اثر خالص اجراى سياست، از روش تفاضل در تفاضل استفاده

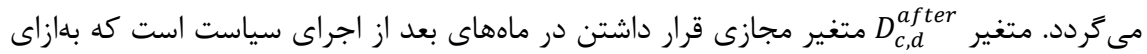

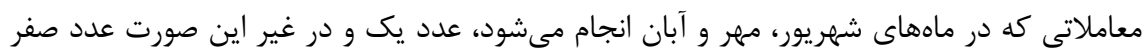

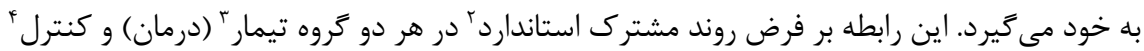

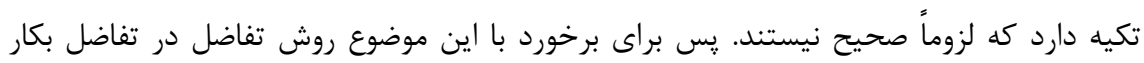

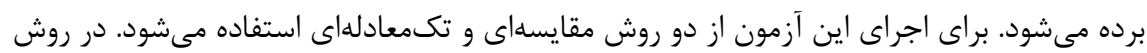
مقايسهاى، ضريب

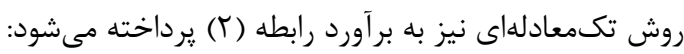

$y_{\boldsymbol{c}, \boldsymbol{d}}=\alpha+\gamma_{\boldsymbol{d}}+\lambda^{\text {after }} D_{\boldsymbol{c}, \boldsymbol{d}}^{\text {after }} \times$ treated $_{\boldsymbol{c}}+$-treated $_{\boldsymbol{c}}+\epsilon_{c, \boldsymbol{d}}$

كه در آن متغير مجازى treated براى گروهى كه اين سياست در موردشان اجرا مىشود برابر يك و براى گروهى كه اين سياست در موردشان اجرا نمىشود، برابر صفر است. شايان اشاره است

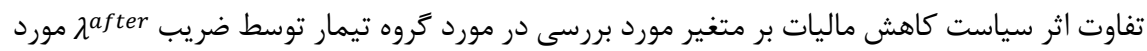

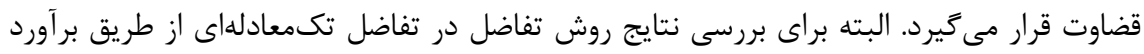

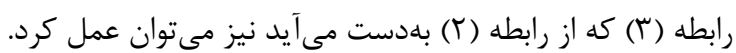

1. Difference-in-Differences (DID)

2. Standard Common Trends Assumption

3. Treatment Group

4. Control Group 
$\Delta y_{c, d}=\theta+\lambda^{a f t e r} \times$ treated $_{c}+\epsilon_{c, d}$

به منظور بررسى تاثير كلى سياست كاهش نرخ ماليات انتقال سهام بر يك معيار كيفيت بازار بورس

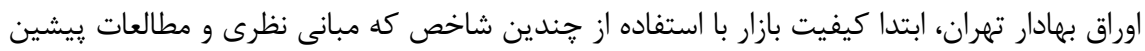

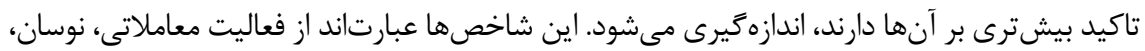

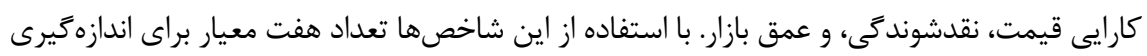
كيفيت بازار ايجاد مىشود كه بهجاى متغير

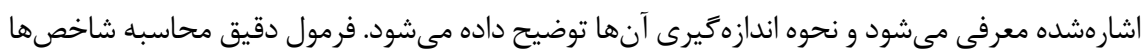
در جدول (1) نيز ارائه شده است.

ا. فعاليت معاملاتى': به صورت لكًاريتم طبيعى ارزش ريالى معاملهشده سهام c در روز d الهده

$$
\text { اندازمخيرى و به صورت Log volume }
$$

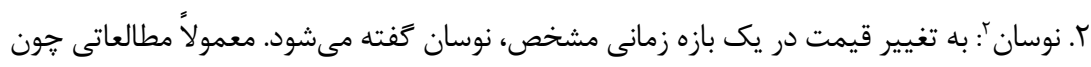

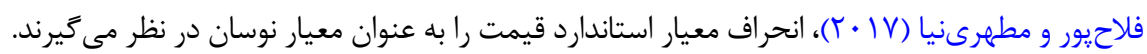

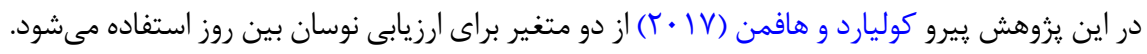
الف. نوسان تحققيافته كه با realized volatility اتفاق افتاده اندازهخيرى مىكند و به صورت حاصلجمع توان دوم بازدهاى ميان روزانه (بر اساس

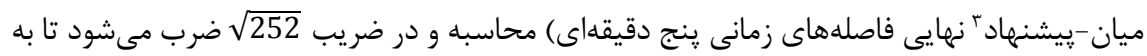
ساليانه تبديل شود، و برحسب درصد نشان داده مىشود. $\sum_{h=0}^{42}\left(r_{c, d, h}-\overline{r_{c, d, h}}\right)^{2} \times 100 \times \sqrt{252}$ realized volatility v,$d$

$r_{c, d, h}=\frac{p_{c, d, h}-p_{c, d, h-1}}{p_{c, d, h-1}}$

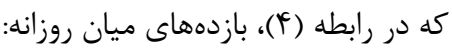

و از آنجا كه بازهها ينج دقيقهاى هستند، در يك روز r r داده براى بازدههاى ميان روزانه وجود

ب. محدوده قيمتى range به صورت محدوده قيمتى بين روز براى تمامى معاملات محاسبه

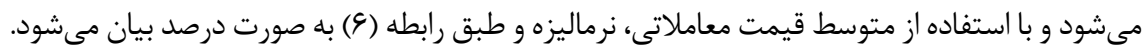
range $_{c, d}=\frac{\operatorname{Max}_{h} p_{c, d, h}-\text { Min }_{h} p_{c, d, h}}{\text { Average }_{h} p_{c, d, h}} \times 100$

1. Trading Activity 
r. كارايى قيمت كه با من منان داده مىشود در مطالعات زيادى همجون

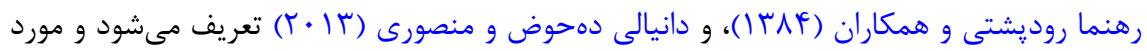
استفاده قرار مى گيرد. قيمتهاى كارا يِيشبينىنايذير هستند، يعنى از مدل گشت تصادفى' تبعيت

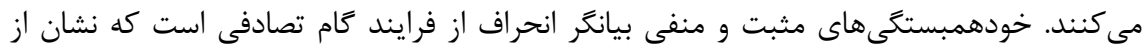
ناكارايى قيمتى سهام است. ناكارايى قيمت به صورت قدر مطلق خودهمبستكى هاى بازدهى درجه اول، بر اساس قيمت ميانه نهايى فاصلههاى زمانى ينج دقيقهاى اندازمكيرى ميىشود.

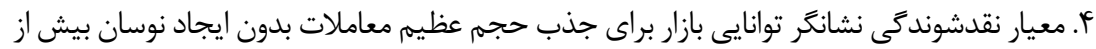
اندازه در قيمتهاست. به عبارت ديكر، نقدشوندگى به معناى توانايى انجام سريع معاملات با هزينه اندكى و بدون تحت تاثير قرار دادن شديد قيمتهاست. بازارهايى با درجه نقدشوندگى مناسب، امكان ورود و خروج

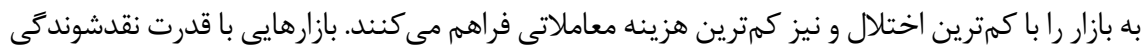

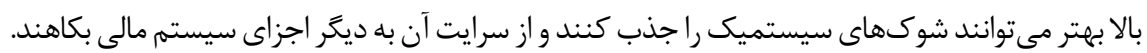
در نتيجه، تاثير بسزايى بر ثبات سيستمهاى مالى دارند و مانع سرايت اثرات نامطلوب نوسان قيمت بر بر ديكر

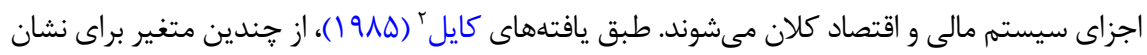

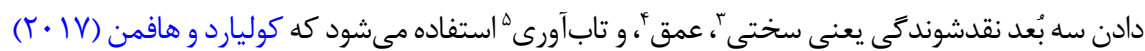

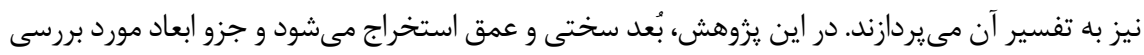

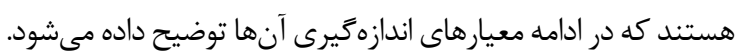

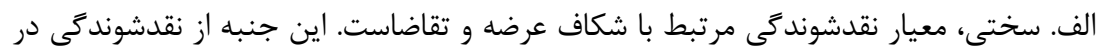

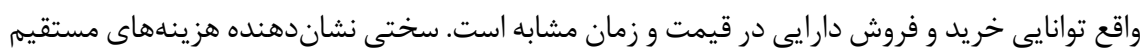

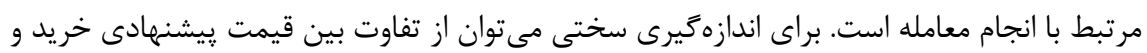

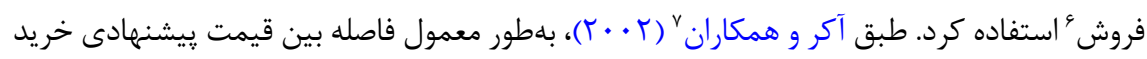
و فروش به صورت روزانه مورد بررسى قرار مى گيرد و هرجه شكاف قيمتى كمتر باشد، نقدشوندگى سهام بالاتر است. براى محاسبه سختى از دو شاخص استفاده مى كنيه:

1. Random Walk

2. Kyle

3 . Tightness

4. Depth

5. Resiliency

6. Spread

7. Acker et al. 
- شكاف مظنه يريشنهادى خريد و فروش': اين معيار اختلاف بين بهترين قيمت بيشنهادى

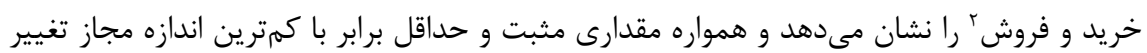

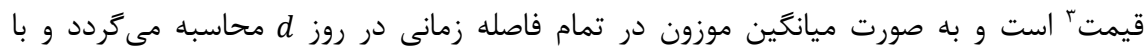

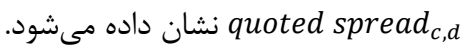

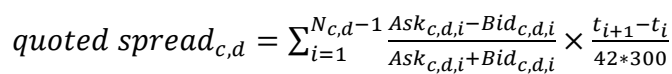
كه در رابطه (V) 300×42 تعداد ثانيههاى موجود در يك روز كارى است.

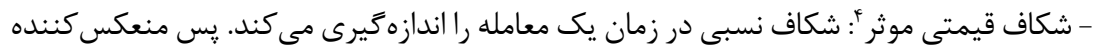
هزينه واقعى معامله انجامشده است. شكاف قيمتى موثر به صورت ميانگين موزون براى تمام معاملات

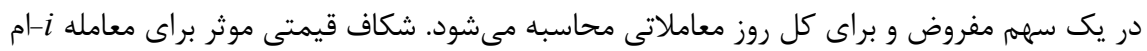

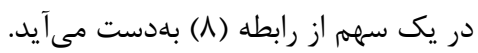

effective spread $t=\sum_{i=1}^{N_{c, d}-1} \frac{p_{c, d, i}-\text { mid }_{c, d, i}}{\text { mid }_{c, d, i}} \times \frac{t_{i+1}-t_{i}}{42 * 300}$

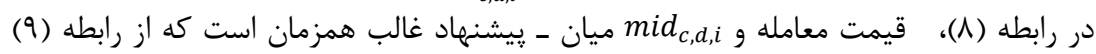
بdدست مى آيد.

$\operatorname{mid}_{c, d, i}=\frac{A s k_{c, d, i}+B i d_{c, d, i}}{2}$

ب. عمق: در حالى كه شكاف قيمت به تخمين زدن هزينههاى معاملاتى معاملات كوخى مربوط

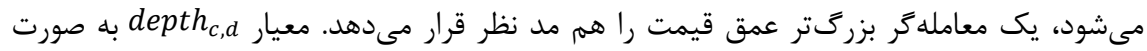
مجموع نقدينكى موجود در شكاف قيمت داخلى (هر دو طرف خريد و فروش) محاسبه مىشود كه به ميه صورت زمانى وزندار در رابطه (• () نمايش داده شده است.

$\operatorname{depth}_{c, d}=\sum_{i=1}^{N_{c, d}-1}\left(\operatorname{vask}_{c, d, i}+\operatorname{vbid}_{c, d, i}\right) \times \frac{t_{i+1}-t_{i}}{42 * 300}$

عمق يك معيار نقدشوندگى مرتبط با حجم است كه توانايى خريد و فروش مقدار مشخصى از دارايى را بدون تاثير در قيمت مظنهها نشان مىدهد. عمق بازار در مطالعات مختلفى تعريف شده است، اما تعريف غالب بر اساس مجموع حجم بهترين سفارش خريد و فروش در بازه مورد بررسى

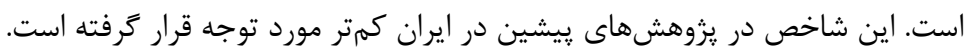

1. Quoted Spread, Dollar Spread or Absolute Spread

2. Ask-Bid Price

3. Tick Size

4. Effective Spread 
جدول ا: تعريف متغيرهاى كيفيت بازار

\begin{tabular}{|c|c|c|c|}
\hline فرمول محاسبه & واحد زمان & 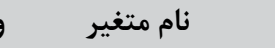 & نام شاخص \\
\hline 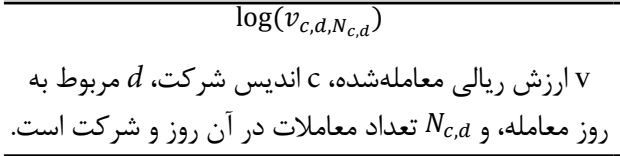 & روز & Log volume $_{c, d}$ & 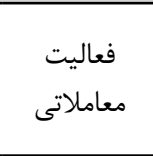 \\
\hline 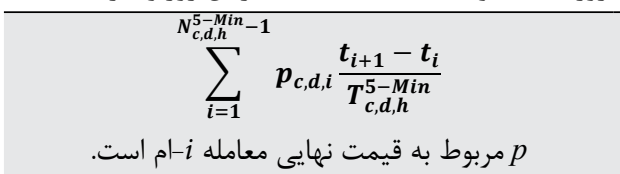 & ه دقيقه & $p_{c, d, h}$ & ميان قيمت \\
\hline$r_{c, d, h}=\frac{p_{c, d, h}-p_{c, d, h-1}}{p_{c, d, h-1}}$ & ه دقيقه & $r_{c, d, h}$ & 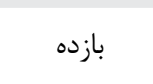 \\
\hline$\sum_{h=0}^{42}\left(r_{c, d, h}-\overline{r_{c, d, h}}\right)^{2} \times 100 \times \sqrt{252}$ & روز & realized volatility $y_{c, d}$ & 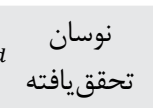 \\
\hline$\frac{\operatorname{Max}_{h} p_{c, d, h}-\operatorname{Min}_{h} p_{c, d, h}}{\text { Average }_{h} p_{c, d, h}} \times 100$ & 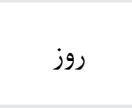 & range $_{c, d}$ & 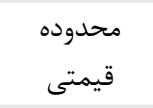 \\
\hline 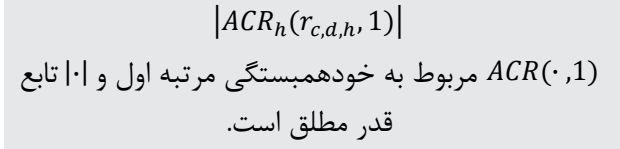 & روز & price_efficienc $_{c, d}$ & كارايى قيمت \\
\hline 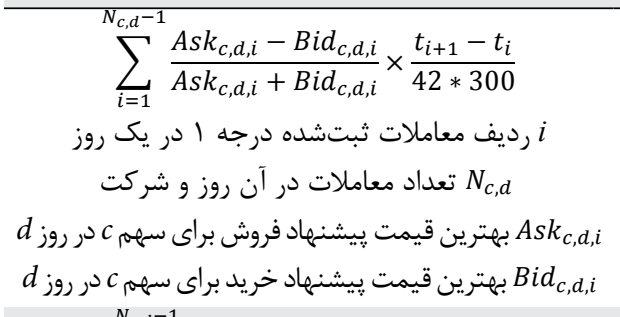 & روز & quoted_spread ${ }_{c, d}$ & 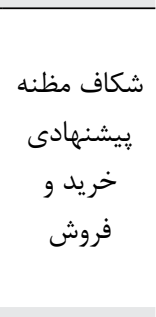 \\
\hline $\begin{array}{c}\sum_{i=1}^{N_{c, d}-1} \frac{p_{c, d, i}-\operatorname{mid}_{c, d, i}}{\operatorname{mid}_{c, d, i}} \times \frac{t_{i+1}-t_{i}}{42 * 300} \\
\operatorname{mid}_{c, d, i}=\frac{A s k_{c, d, i}+B i d_{c, d, i}}{2} \\
\text { هيشان } \operatorname{mid}_{c, d, i}\end{array}$ & روز & effective_spread & شكاف قيمتى \\
\hline 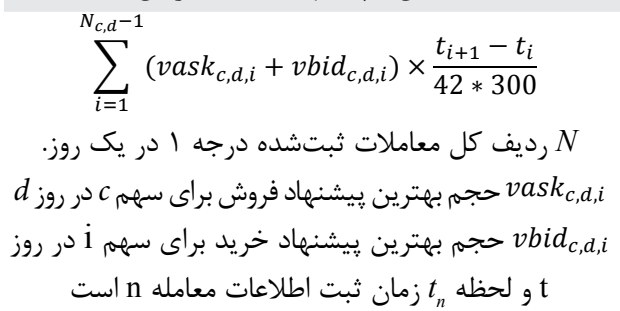 & روز & $d e p t h_{c, d}$ & عمق بازار \\
\hline
\end{tabular}




\section{جمع آورى دادهها}

در اين يزوهش براى ايجاد و محاسبه شاخصهاى كيفيت بازار از دادهاى فركانس بالا' كه

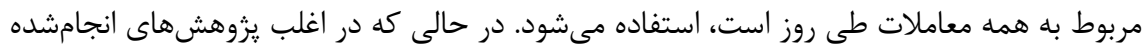

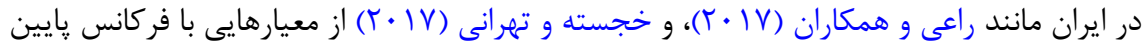
كه جمع آورى داده و محاسبات آنها سادهتر بوده، استفاده شده است. در ادامه، روش جمع آورى داده بزرگى كه در اين يزوهش مورد استفاده قرار گرفته، توضيح داده مىشود.

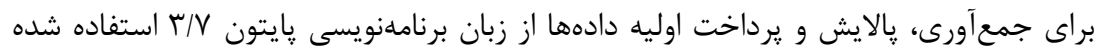
است. در راستاى انجام اهداف تعيينشده، دادههاى معاملاتى همه نمادهاى فعال در بازه زمانى تير تا

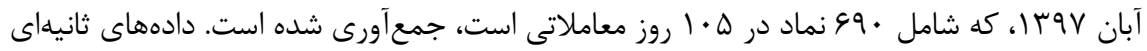

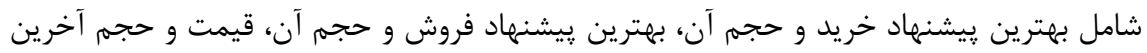

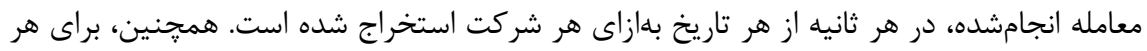
شركت و هر تاريخ، دادههاى روزانه شامل ارزش بازار، قيمت يايانى، و ارزش معاملات نيز استخراج شده لهر

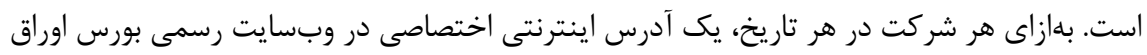

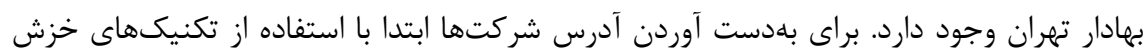

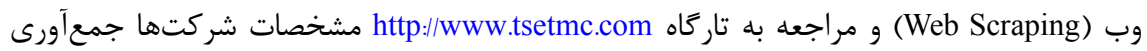
شدند و با توجه به كد اختصاصى هر شركت كه در آدرس صفحه آن وجود دارد، آدرس شركت مورد نظر در تاريخ مورد نظر ايجاد شد.

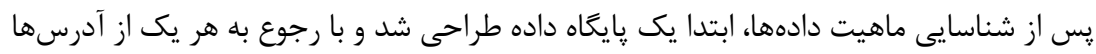
داده مورد نظر در هر ثانيه از صفحههاى مربوطه جمعآورى كرديد. هرجند اين فرايند به صورت

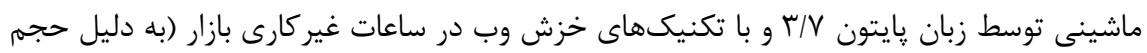

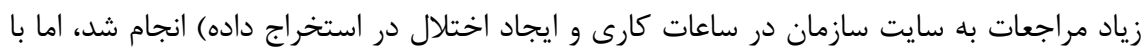

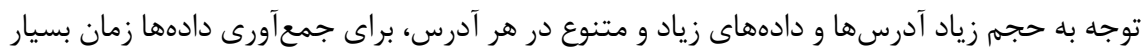

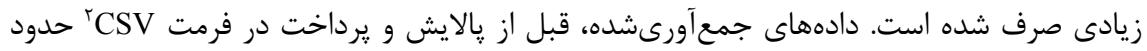
q كيعابايت و بالغ بر يك ميليارد و سيصد ميليون ركورد بود. اين ركوردها شامل همه دادهها از همه شركتهاى ثبتشده در بورس در بازه زمانى مورد بررسى است. شايان ذكر است در مرحله تبديل 
داده به اطلاعات، طبق جدول ( ()، براى محاسبه عمق بازار به صورت دقيقهاى عمل شده است و فقط دقايقى در نظركرفته شدند كه در طول دقيقه حداقل سه معامله انجام شده باشد.

\section{يافته هاى ثزوهش}

با استفاده از دادههاى استخراجشده كه يالايش و يرداخت شدهاند و مطابق با روابط ارائهشده در جدول (1)، متغيرهاى كيفيت بازار ساخته مىشوند. ميانحين هفت شاخص كيفيت بازار محاسبه و واده

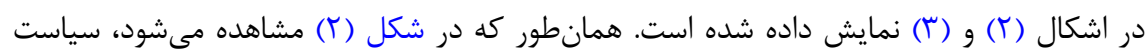

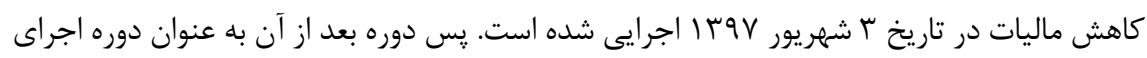

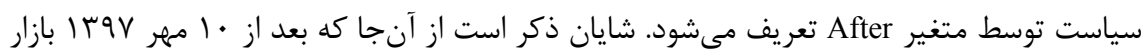
دجار نوسانات شديدى شده، اطلاعات بعد از اين تاريخ از داده حذف شده است. همجنين، اكر اين داده را وارد تخمين كنيم، معنادارى نتايج از بين مىرود. بنابراين، در مورد تفسير آثار نتايج در بلندمدت لمدات بايد احتياط كرد.

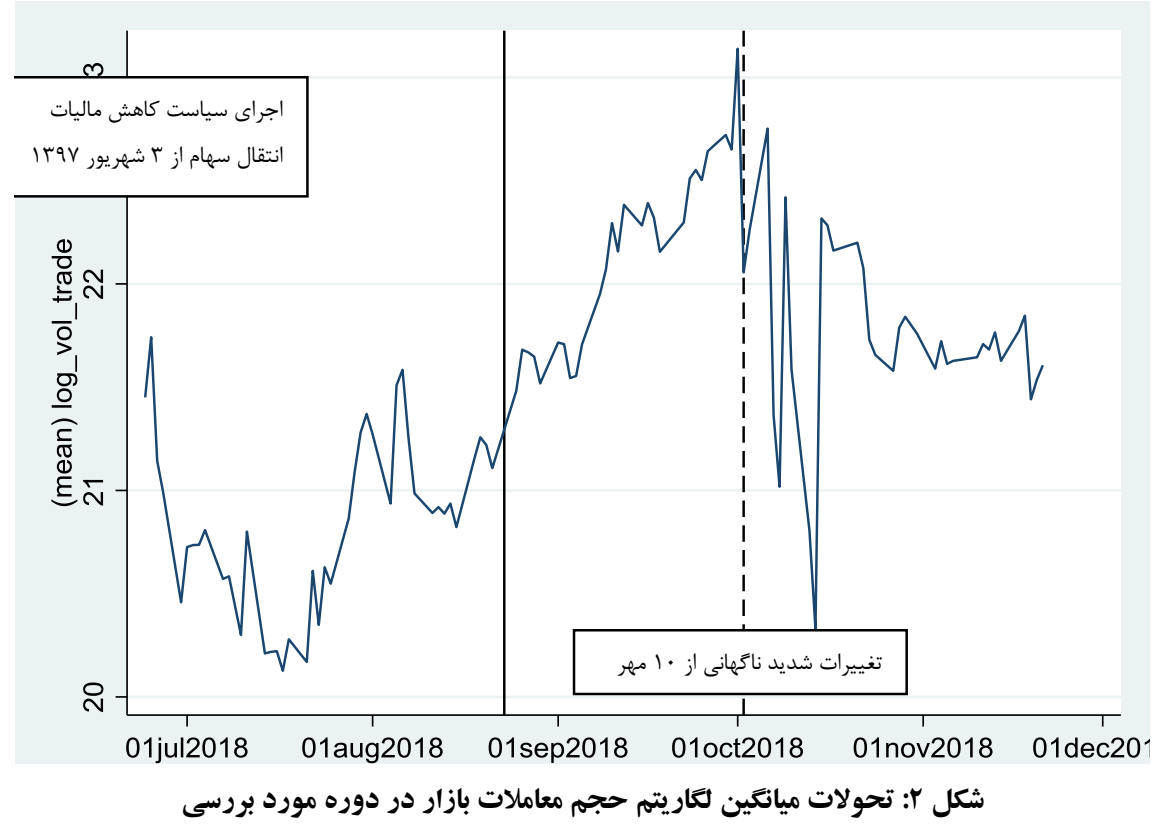


آنجه در شكل (r) مشاهده مىشود، نتيجه تعديلى جندمرحلهاى است و صرفاً تصورى كلى از ماجرا بهدست مىدهد. در اين شكل ابتدا دادههاى ثانيهاى طبق تعريف رديف اول جدول (1) به

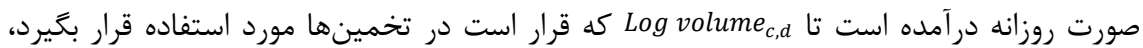
بهازاى هر شركت c در روز d بهدست بيايد. آنجه در شكل (Y) مشاهده مىشود، ميانگين معيار

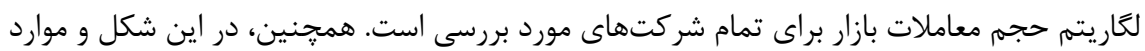

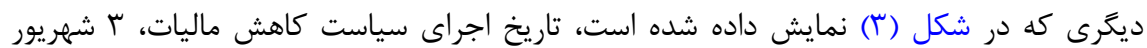

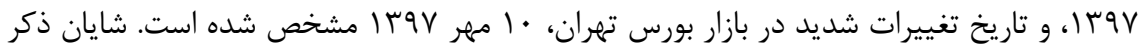

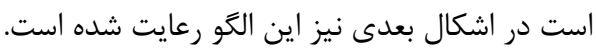
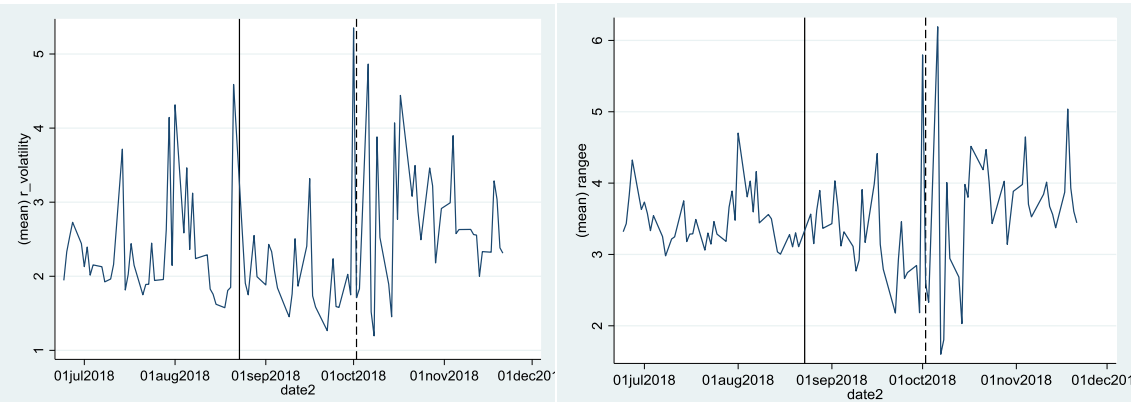

تحولات محدوده قيمتى (بازه نوسان) متوسط بازار در تحولات نوسان تحققيافته متوسط بازار در دوره مورد بررسى

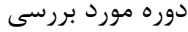
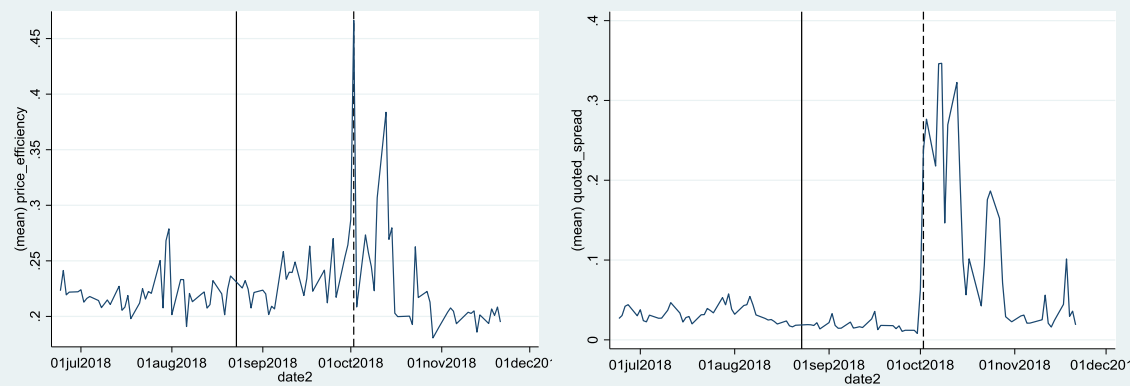

تحولات كارايى قيمت متوسط بازار در دوره مورد بررسى تحولات شكاف مظنه ييشنهادى خريد و فروش متوسط بازار در دوره مورد بررسى حطى لينهادي 


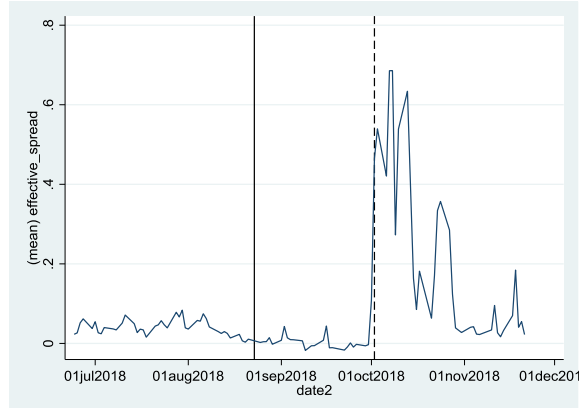

تحولات شكاف قيمتى موثر متوسط بازار در دوره

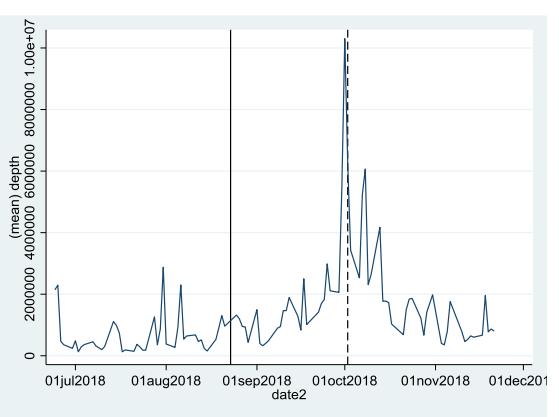

تحولات عمق متوسط بازار در دوره مورد بررسى مورد بررسى

شكل س: تحولات ميانغين ساير معيارهاى كيفيت بازار در دوره مورد بررسى

بر اساس آنجه در شكل (ب) نمايش داده شده است، هماهنگى تغييرات بهدستآمده در انواع معيارهاى ارائهشده بعد از • ا مهر لو با خود دليلى بر اعتبار داده مورد بررسى اين مطالعه است.

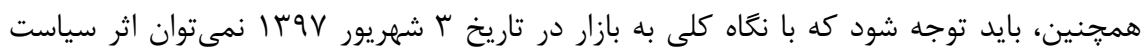

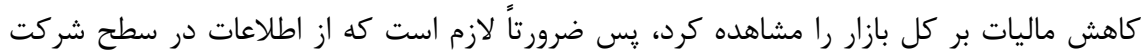
بهدست آيد كه در اين يزوهش استفاده شده است. در جدول (Y)، نتايج برآورد رابطه (Y) منعكس شده است. البته بايد اشاره كرد كه اثرات ثابت زمانى در اين تخمينها در نظركرفته نشده است. طبق ستون نخست اين نتايج، قرار كرفتن در دور دوره

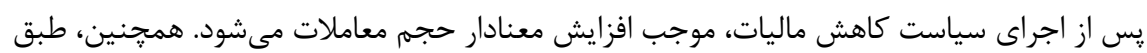
نتايج ارائهشده در ستونهاى دوم و سوم جدول (Y)، اجراى سياست كاهش ماليات انتقال سهام، نوسان را كاهش داده است. نتايج ستون ينجم و ششم نيز بيانكر اين موضوع است. از سوى ديكر،

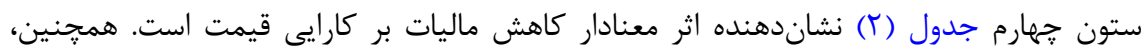
كاهش ماليات موجب افزايش عمق بازار شده است. 
جدول r: نتايج تخمين DID بر معيارهاى كيفيت بازار

\begin{tabular}{|c|c|c|c|c|c|c|c|}
\hline متغير ها & $\begin{array}{c}\log _{-} \text {vol_- } \\
\text { trade }\end{array}$ & $\begin{array}{c}\mathbf{r}_{-} \\
\text {volatility }\end{array}$ & Range & $\begin{array}{c}\text { price_- } \\
\text { efficiency }\end{array}$ & $\begin{array}{c}\text { quoted_- } \\
\text { spread } \\
\end{array}$ & $\begin{array}{c}\text { effective } \\
\text { spread } \\
\end{array}$ & Depth \\
\hline \multirow[t]{2}{*}{ treated } & $-\cdot / r V Y^{*}$ & $-\cdot|r \Delta|$ & T/TII" & $-\cdot / \cdot r \Delta^{* * * *}$ & $\cdot / \cdot \mu^{*}$ & $\cdot 1 \cdot 1^{* * m^{*}}$ & $-.1 \cdot 9$ \\
\hline & $(\cdot / \cdot V)$ & $(\cdot / \pi)$ & $(\cdot / 1 \wedge)$ & $(\cdot / \cdot 1)$ & $(\cdot / \cdot r)$ & $(\cdot / \cdot r)$ & $(\cdot / \mid \Delta \varphi)$ \\
\hline \multirow[t]{2}{*}{ After treated } & $\cdot|0| 9^{* * * *}$ & $-\cdot / r \Delta^{*}$ & $-\cdot / 191^{* * * *}$ & $\cdot / \cdot 1^{* \text { *wan }}$ & $-\cdot / \cdot \cdot V^{*}$ & $-\cdot / \cdot \gamma^{*}$ & $\cdot / 9 \Delta^{* a s}$ \\
\hline & $(\cdot / \cdot 1)$ & $(\cdot / 1 T)$ & $(\cdot / \cdot r)$ & $(\cdot / \cdot r)$ & $(\cdot / \cdot \cdot 1)$ & $(\cdot / \cdot \cdot 1)$ & $(\cdot / \cdot V)$ \\
\hline \multirow[t]{2}{*}{ Constant } & 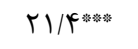 & 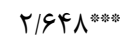 & $|/ T|^{\prime 3}$ & - / YFY & $\cdot / \cdot \Upsilon^{*}$ & $\cdot / \cdot r V^{*}$ & $\cdot / V I^{*}$ \\
\hline & $(\cdot / 14 q)$ & $(\cdot / r q)$ & $(\cdot / / \vee \Delta)$ & $(\cdot / \cdot \wedge)$ & $(\cdot / \cdot r)$ & $(\cdot 1 \cdot 9)$ & $(\cdot / T \vee q)$ \\
\hline Observations & TF/TGY & Tr/TEQ & TT/TEA & $19 / 9 V F$ & $r r / F \Delta I$ & $r T / F \Delta I$ & TH/FDI \\
\hline company & FTT & rVA & rVA & rVr & FIV & fiv & FIV \\
\hline
\end{tabular}

در جدول (ץ)، به روش متفاوتى عمل شده و نتايج اثر كذر زمان اجراى سياست بر كروه تيمار

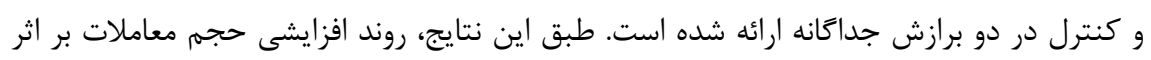
سياست كاهش ماليات تقويت شده است. كاهش ماليات از سوى ديكر، تفاوت غيرمعنادار نوسان بعد دئ دان

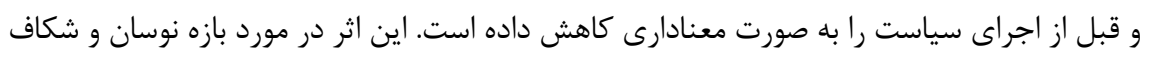

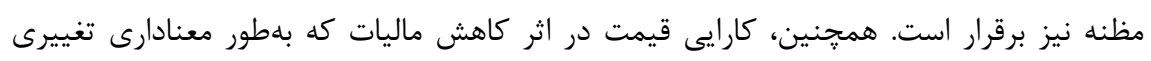

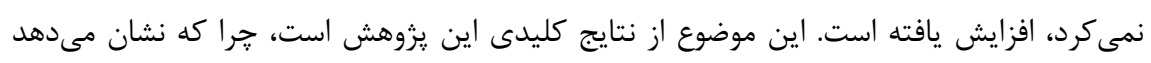

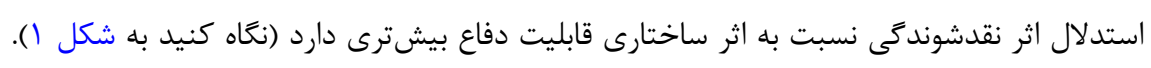

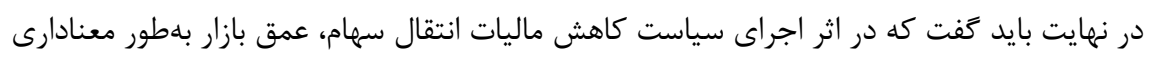

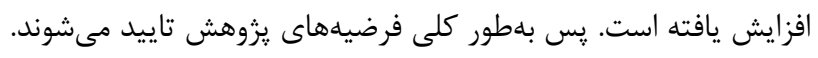


جدول ז: نتايج تخمين روند زمانى مقايسه كروه تيمار و كنترل

\begin{tabular}{|c|c|c|c|c|c|}
\hline متغير ها & & After & Constant & Observations & Number of Companies \\
\hline log_vol_trade & treat & $\begin{array}{l}1 / T Y Q^{* * * *} \\
(\cdot / \cdot 19)\end{array}$ & $\begin{array}{l}r \cdot / V \Lambda^{\text {**:*as }} \\
(\cdot / l \cdot \Delta)\end{array}$ & TI/QVG & raf \\
\hline log_vol_trade & control & $\begin{array}{l}\cdot / \mathcal{q} q * * * * \\
(\cdot / 1 / r)\end{array}$ & $\begin{array}{l}19 / 09 * * * \\
(\cdot / 09)\end{array}$ & 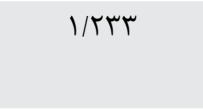 & TF \\
\hline r_volatility & treat & 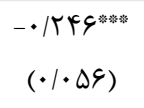 & 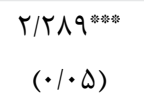 & r r r & raf \\
\hline r_volatility & control & $\begin{array}{l}-r / \varepsilon \wedge T \\
(r / Y \wedge \Delta)\end{array}$ & $\begin{array}{l}f / / 9 Y^{* * *} \\
(1 / 9 \cdot 9)\end{array}$ & $1 / \mu_{\Delta}$ & TF \\
\hline rangee & treat & $\begin{array}{l}-\cdot /\left.19\right|^{\text {*as }} \\
(\cdot / \cdot r F)\end{array}$ & 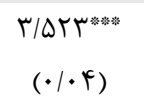 & rI/Tr. & raf \\
\hline rangee & control & $\begin{array}{l}-. / .9 \Lambda \\
(\cdot / r T)\end{array}$ & 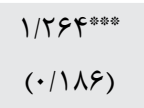 & $1 / r \Delta$ & TF \\
\hline price_efficiency & treat & $\begin{array}{l}\cdot / \cdot 1^{* \text { *as }} \\
(\cdot / \cdot r)\end{array}$ & 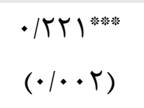 & IN/VqT & raf \\
\hline price_efficiency & control & $\begin{array}{l}. / \cdot .9 \\
(\cdot / \cdot 1)\end{array}$ & $\begin{array}{l}\cdot / Y Y \Lambda^{m * n} \\
(\cdot / \cdot V)\end{array}$ & $\wedge \wedge 1$ & r \\
\hline quoted_spread & treat & $\begin{array}{c}-\cdot / \cdot 19^{* * b} \\
(\cdot / \cdot 1)\end{array}$ & 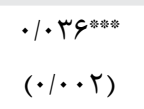 & TI/IGT & raf \\
\hline quoted_spread & control & $\begin{array}{l}\cdot / \cdot r \\
(\cdot / \cdot r)\end{array}$ & $\begin{array}{l}\cdot / \cdot r Q^{* * *} \\
(\cdot / \cdot \mid r)\end{array}$ & $1 / \cdot 19$ & rF \\
\hline effective_spread & treat & $\begin{array}{l}-\cdot / \cdot \varphi^{\text {cownos }} \\
(\cdot / \cdot \cdot r)\end{array}$ & 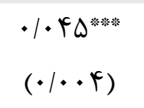 & TI/IGT & raF \\
\hline effective_spread & control & $\begin{array}{l}\cdot / \cdot r \\
(\cdot / \cdot \Lambda)\end{array}$ & $\begin{array}{l}\cdot / \cdot Y^{*} \\
\left(\cdot / \cdot Y^{*}\right)\end{array}$ & $1 / \cdot 19$ & Tr \\
\hline depth & treat & 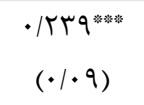 & 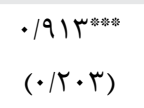 & TI/Igr & rar \\
\hline depth & control & $\begin{array}{l}\cdot / \cdot \varphi^{* *} \\
(\cdot / \cdot \mid V)\end{array}$ & $\begin{array}{l}\cdot / \mid \uparrow \Lambda^{* \omega *} \\
(\cdot / \cdot \Delta \varepsilon)\end{array}$ & $1 / \cdot 19$ & TF \\
\hline
\end{tabular}




\section{بحث و نتيجه Fيرى}

در اين يزوهش با استفاده از دادههايى با فركانس بالا براى بr شF شركت در بازه زمانى تير تا آبان

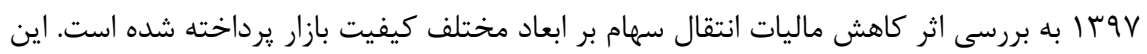

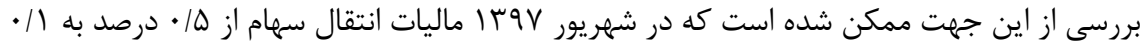
درصد كاهش يافته است. با استفاده از اين حقيقت كه صندوقهاى سرمايدگذارى از اين ماليات معاف هستند، از روش تفاضل در تفاضل، اثر كاهش ماليات انتقال سهام در شهريور

يافتههاى يزوهش نشان مىدهند، كاهش ماليات انتقال سهام، كيفيت بازار را در تمام ابعاد مورد بررسى افزايش داده است. يس نظريه اثر نقدشوندگى نسبت به نظريه رقيب آن، يعنى اثر ساختارى،

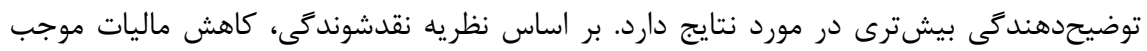

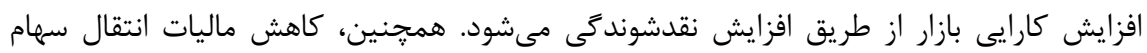

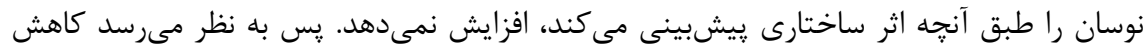

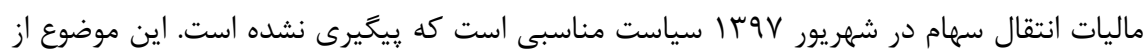

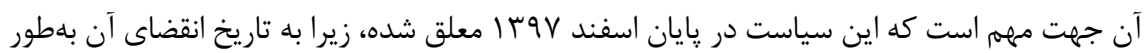
شفاف اشاره نشده است. در نتيجه، مصوبه سال VY I شوراى عالى هماهنگى اقتصادى منقضى شده

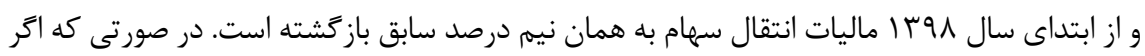

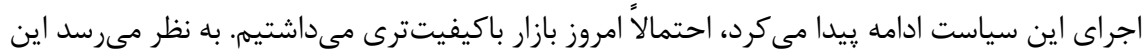

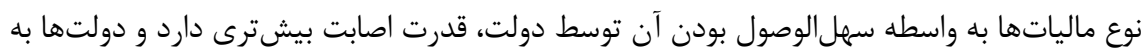
سراغ آن مىروند، اما جنانجه سياستخذار به دنبال افزايش كيفيت بازار باشد، به نظر كاهش ماليات

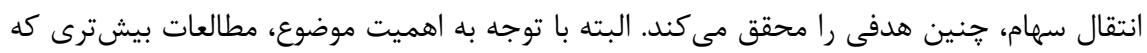

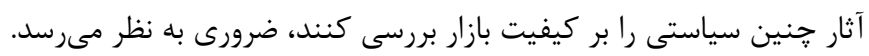

Acker, D., Stalker, M., \& Tonks, I. (2002). Daily Closing Inside Spreads and Trading Volumes around Earnings Announcements. Journal of Business Finance \& Accounting, 29(9-10), 1149-1179. https://doi.org/10.1111/1468-5957.00465 
Amihud, Y., \& Mendelson, H. (1986). Asset Pricing and the Bid-Ask Spread. Journal of Financial Economics, 17(2), 223-249. https://doi.org/10.1016/0304-405X(86)90065-6

Atrchi, R., \& Ramtinnia, S. (2018). An Investigation of Methods to Reduce Transaction Costs in Tehran Stock Exchange. Journal of Investment Knowledge, 7(26), 17-30. http://jik.srbiau.ac.ir/article_12592.html

Bagheri, B., Omidipour, R., \& Aminkhaki, A. (2014). Investigating the Relationship between Tax Exemption of the Article 143 of the Iranian Direct Tax Act and Stock Return of the Companies Listed in Tehran Stock Exchange. Journal of Tax Research, 22(23), 9-35. http://taxjournal.ir/article-1-444-fa.html

Capelle-Blancard, G., \& Havrylchyk, O. (2016). The Impact of the French Securities Transaction Tax on Market Liquidity and Volatility. International Review of Financial Analysis, 47(1), 166-178. https://doi.org/10.1016/j.irfa.2016.07.002

Colliard, J. E., \& Hoffmann, P. (2017). Financial Transaction Taxes, Market Composition, and Liquidity. The Journal of Finance, 72(6), 2685-2716. https://doi.org/10.1111/jofi.12510

Constantinides, G. M. (1986). Capital Market Equilibrium with Transaction Costs. Journal of Political Economy, 94(4), 842-862. https://doi.org/10.1086/261410

Daniali Dehouzi, M., \& Mansouri, H. (2013). Investigating Weak Form of Efficiency in Tehran Stock Exchange and Ranking Factors that Affect It. Economics Research, 12(47), 71-96. http://joer.atu.ac.ir/article_931.html

Dávila, E., \& Parlatore, C. (2021). Trading Costs and Informational Efficiency. The Journal of Finance, 76(3), 1471-1539. https://doi.org/10.1111/jofi.13008

Fallahpour, S., \& Motaharinia, V. (2017). Including Jump Components in Modeling and Forecasting Realized Volatility: Evidence from Tehran Stock Exchange. Financial Engineering and Portfolio Management, 8(32), 171-190. http://fej.iauctb.ac.ir/article_533500.html

Keynes, J. M. (1936). The General Theory of Employment, Interest and Money: Palgrave Macmillan.

Khojasteh, M. A., \& Tehrani, R. (2017). Asset Pricing Model On The Basis Of Liquidity Risk Factor. Financial Knowledge of Securities Analysis, 10(35), 1-17. http://jfksa.srbiau.ac.ir/article_10660.html

Kyle, A. S. (1985). Continuous Auctions and Insider Trading. Econometrica: Journal of the Econometric Society, 53(6), 1315-1335. https://doi.org/10.2307/1913210

Mani, K., Pajooyan, J., \& Mohammadi, T. (2011). Analysis of the Effect of Taxes on the Relationship between Financial Markets and Economical Growth. Journal of Economics Research, 11(42), 13-37.

Mousavi Jahromi, Y., Razavi, M. R., Khodadad Kashi, F., \& Eizadi, S. H. (2017). Study of Regional Development Targeted Incentives Using DID Approach, Case Study: Tax Exemptions Article 132 of Direct Tax Act. Quarterly Journal of Economic Growth and Development Research, 7(28), 33-50. http://egdr.journals.pnu.ac.ir/article_3480.html

Ogden, J. P., Jen, F. C., \& O'Connor, P. F. (2003). Advanced Corporate Finance: Policies and Strategies: Pearson College Division.

Raei, R., Eivazlu, R., \& Abbaszadeh Asl, A. A. (2017). Investigation on relation between information asymmetry and liquidity via market microstructures model in Tehran Stock Exchange. Financial Knowledge of Securities Analysis, 10(34), 13-24. 
http://jfksa.srbiau.ac.ir/article_10601.html

Ross, S. A. (1989). Commentary: Using Tax Policy to Curb Speculative Short-Term Trading. In Regulatory Reform of Stock and Futures Markets (pp. 19-22): Springer. https://doi.org/10.1007/978-94-009-2193-1_3

Schwert, G. W., \& Seguin, P. J. (1993). Securities Transaction Taxes: An Overview of Costs, Benefits and Unresolved Questions. Financial Analysts Journal, 49(5), 27-35. https://doi.org/10.2469/faj.v49.n5.27

Song, F. M., \& Zhang, J. (2005). Securities Transaction Tax and Market Volatility. The Economic Journal, 115(506), 1103-1120. https://doi.org/10.1111/j.1468-0297.2005.01034.x

Stiglitz, J. E. (1989). Using Tax Policy to Curb Speculative Short-Term Trading. Journal of Financial Services Research, 3(2), 101-115. https://doi.org/10.1007/BF00122795

Summers, L. H., \& Summers, V. P. (1989). When Financial Markets Work Too Well: A Cautious Case for a Securities Transactions Tax. Journal of Financial Services Research, 3(2-3), 261-286. https://doi.org/10.1007/BF00122806

Vayanos, D. (1998). Transaction Costs and Asset Prices: A Dynamic Equilibrium Model. The Review of Financial Studies, 11(1), 1-58. https://doi.org/10.1093/rfs/11.1.1

$$
\begin{aligned}
& \text { ب) فارسى } \\
& \text { رضايى، محمدقاسم؛ سبزرو، محبوبه، و رضايىيور، محمد ( (Y ب (). آزمون اثرات مشوقهاى مالياتى (شواهدى در }
\end{aligned}
$$

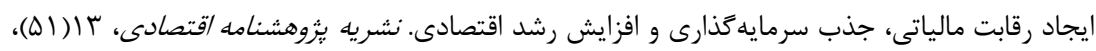

$$
\begin{aligned}
& \text { http://joer.atu.ac.ir/article_413.html lqr-IAV }
\end{aligned}
$$

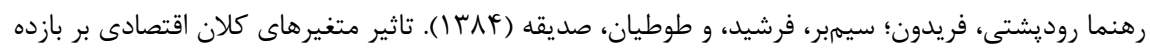

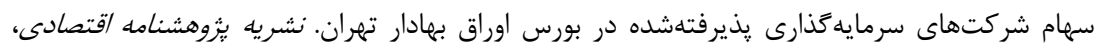

$$
\begin{aligned}
& \text { T }
\end{aligned}
$$

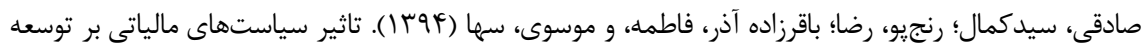

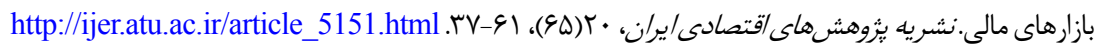

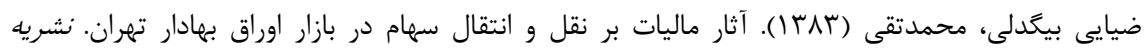

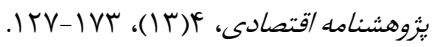

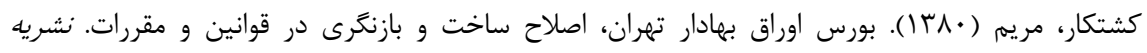

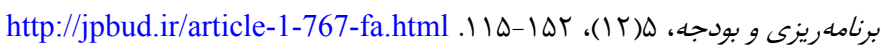

